\title{
Psychometric and Validity Evidence of the Fear of Being Single Scale
}

\author{
Patrícia Nunes da Fonseca ${ }^{1}$ \\ Center for Education, Department of Psychopedagogy, Federal University of Paraiba, \\ João Pessoa, PB, Brazil \\ Valdiney Veloso Gouveia \\ Jérssia Laís Fonseca dos Santos \\ Ricardo Neves Couto \\ Postgraduate Program in Social Psychology, Federal University of Paraiba, \\ João Pessoa, PB, Brazil \\ Gabriel Lins de Holanda Coelho \\ School of Psychology, Cardiff University, País de Gales, UK
}

\begin{abstract}
The fear of being single can lead to changes in the quality of life of individuals, which may affect their well-being and self-esteem. This research aimed to validate the Fear of Being Single Scale (FBSS) for Brazil, presenting evidence of its psychometric quality through two studies. Study 1 had 172 participants (Age $M=23.69, S D=7.77 ; 64.5 \%$ women) and replicated the one-factor structure of the instrument, with six items. Study 2 had 220 participants (Age $M=21.90, S D=5.64 ; 59.5 \%$ women) and confirmed the structure using a CFA, with satisfactory indices (CFI $=.96$; TLI $=.94)$, and provided evidence for the factorial invariance of the instrument, in relation to participants' relationship status. Additionally, convergent validity was presented through significant correlations with loneliness and life satisfaction scores, and a difference was also observed between men and women regarding the fear of being single. Finally, the scale showed adequate levels of reliability (Cronbach's alpha, $\alpha=0.88$ ) and composite reliability $(\mathrm{CR}=0.82)$. In conclusion, the scale presented satisfactory evidence for its use in a Brazilian context.
\end{abstract}

Keywords: Fear of being single, scale, psychometric evidence.

\section{Medo de Ficar Solteiro: Evidências Psicométricas e de Validade de uma Medida}

\section{Resumo}

O medo de ficar solteiro pode ocasionar alterações na qualidade de vida dos indivíduos, podendo afetar o bem-estar e a autoestima. Esta pesquisa teve por objetivo validar a Escala Medo de Ficar Solteiro (EMFS) para o Brasil, apresentando evidências de sua qualidade psicométrica por meio de dois estudos. Estudo 1 contou com 172 participantes (Idade $M=23,69, D P=7,77 ; 64,5 \%$ mulheres) e reproduziu a estrutura unifatorial do modelo original, com seis itens. O Estudo 2 contou com 220 participantes (Idade $M=21,90, D P=5,64 ; 59,5 \%$ mulheres) e confirmou a estrutura por meio de uma AFC, com

Mailing address: Federal University of Paraíba, Center for Education, Department of Psychopedagogy, João Pessoa, PB, Brazil 58051-900. E-mail: pnfonseca.ufpb@gmail.com and linshc@gmail.com

Agradecimentos: Coordenação de Aperfeiçoamento de Pessoal de Nível Superior (CAPES), por bolsa de Doutorado Pleno concedida ao último autor. 
índices satisfatórios $(\mathrm{CFI}=0,96$; TLI $=0,94)$, além de fornecer evidência quanto a invariância fatorial do instrumento em relação ao status de relacionamento dos participantes. Adicionalmente, apresentou-se validade convergente por meio de correlações significativas com solidão e escore de satisfação com a vida, além de ter sido observada diferença entre homens e mulheres quanto ao medo de ficar solteiro. Por fim, a medida apresentou índices adequados de confiabilidade (alfa de Cronbach, $\alpha=0,88$ ) e confiabilidade composta $(\mathrm{CC}=0,82)$. Concluindo, a medida apresentou evidências satisfatórias para o seu uso no contexto brasileiro.

Palavras-chave: Medo de ficar solteiro, escala, evidências psicométricas.

\section{Miedo a Estar Sola: Evidencias Psicométricas y de Validez de una Medida}

\section{Resumen}

El miedo a estar soltero puede conducir a modificaciones en la calidad de vida de los individuos, que pueden afectar su bienestar y autoestima. Esta investigación tuvo como objetivo validar la Escala Miedo a Estar Soltero (EMES) en Brasil, presentando evidencias de su calidad psicométrica a través de dos estudios. Estudio 1 contó con 172 participantes (Edad $M=23.69, D E=7,77 ; 64,5 \%$ mujeres) y se replica la estrutura unifactorial del instrumento, con seis ítems. Estudio contó con 220 participantes (Edad $M=$ $21.90, D E=5,6 ; 59,5 \%$ mujeres) y confirmó la estructura mediante una AFC, con índices satisfactorios $(\mathrm{CFI}=.96 ; \mathrm{TLI}=.94)$, y proporcionó evidencia de la invariancia factorial del instrumento, en relación al estado de relacionamento dos Participantes. Además, sí presenta validez convergente a través de correlaciones significativas con la soledad y la pontuación de satisfacción con la vida, y se ha observado diferencia entre hombres y mujeres cuando el miedo a estar soltero. Por último, la medida mostró niveles adecuados de fiabilidad (alfa de Cronbach, $\alpha=0,88)$ y fiabilidad compuesta $(\mathrm{CC}=0,82)$. En conclusión, la medida presenta pruebas satisfactorias para su uso en el contexto brasileño.

Palabras clave: Miedo estar soltero, escala, pruebas psicométricas.

The fear of being single can be characterized as a concern, anguish, or anxiety in relation to a current or potential experience of not having a romantic partner (Spielmann et al., 2013). This situation can make the individual feel insecure, especially about their physical and social capabilities. This is further aggravated by the pressures from family and society to establish romantic relationships (Schwartzberg, Berliner, \& Jacob, 1995), considered to be a natural and fundamental step on the path to happiness. In the American culture, for example, it has been observed that those who find romantic partners, marry, and have children are happier, less lonely, and more mature. This is probably because they feel more complete and have a more stable emotional life compared with singles (DePaulo $\&$ Morris, 2005). This can be observed in a study by Sharp and Ganong (2007), where unmarried women, seeing that they could not attain a stable relationship during an important period in their lives, become anxious and doubtful about their future.

However, Almeida (2015) highlighted the fact that some individuals have reasons to stay single, particularly those who value independence and self-preservation. In being single, they see the advantage of not being emotionally dependent on a partner; therefore, they have the freedom to relate to more than one person without having to explain themselves or modify their routine to please someone else. In these cases, individuals maintain a lifestyle that meets their personal needs.

In addition, Gonçalves (2011) emphasized that the choice of staying single is associated with the idea of autonomy and is therefore linked to individualization. Furthermore, Gonçalves 
(2011) highlighted that the new generation of women, the so-called "new single women," are characterized as independent, well-educated, fit, successful, with an intense social life, and selective, besides considering themselves beautiful and happy.

DePaulo (2014) stated that people who are unafraid of being single have three main advantages: (a) they are self-confident, (b) have high standards, and (c) are desirable. The first refers to personality - these people are more confident, open and outgoing, less neurotic, and less sensitive to rejection; the second relates to being more selective and demanding in their relationships being very likely to end a relationship, for example, when it is no longer satisfactory; and finally, the third advantage relates to being desirable that is, single people can be more caring and responsive and are, consequently, more attractive.

However, DePaulo (2014) indicated that the perception about single people, especially that they are unhappy, lonely, and loveless, has favored the emergence of different stereotypes, such as people with a "less exciting" and "sadder" life (DePaulo \& Morris, 2005). Records of these stereotypes have accompanied single people from past decades (Etaugh \& Malstrom, 1981) up to the present day (Greitemeyer, 2009; Morris, Sinclair, \& DePaulo, 2007).

Etaugh and Malstrom (1981) demonstrated that differences exist between married people and those who are single with regard to perception. They found that the former are perceived positively as opposed to singles who, according to Conley and Collins (2002), are considered to be less responsible and more promiscuous. Following these differences attributed to single and married people, Morris et al. (2007) conducted a series of experiments to investigate the degree to which people discriminate between these two groups. The participants, in a hypothetical situation, evaluated potential tenants and chose a person to whom they would rent a house. The results showed that the majority of participants preferred people who were in a relationship over those who were not.

As shown, the strong pressure exerted by society, the result of existing stereotypes, leads to a continuous search for social contacts and may become an obstacle to personal growth (Osin \& Leontiev, 2013). Adamczyk and Segrin (2015) indicated that single participants showed a lower level of life satisfaction and social support, in addition to higher scores of loneliness than those who were in some type of relationship.

We can also observe the influence of this social pressure on the self-esteem of individuals, which strongly jeopardizes the establishment of affective relationships. Kavanagh, Robins, and Ellis (2010) observed that self-esteem is influenced by romantic rejections, thus resulting in low levels of aspirations for a prospective partner. Hirschberger, Florian, and Mikulincer (2002) found that the level of self-esteem of students was directly proportional to their desired standards in a partner. This implies that an individual with low self-esteem probably would have lower standards than those with higher self-esteem.

Spielmann et al. (2013) focused on experiences about being single, as, according to them, such studies were limited. Thus, considering the definition literally, a person who is in a relationship would have this problem solved. However, this fear is not something that is necessarily solved by finding a romantic partner; therefore, controlling it is imperative. From the aforementioned considerations, the need to find ways more specific to measure the phenomenon is made clear. This led Spielmann et al. (2013) to create an instrument that best expressed the fear of being alone, which can lead people to accept partners below previous expectations.

\section{Fear of Being Single Scale}

Spielmann et al. (2013) identified a few instruments (e.g., interviews and narratives) that qualitatively evaluated the fear of being single. However, no psychometric scale could assess this construct. Given this fact, the authors developed the Fear of Being Single Scale (FBSS) as an instrument capable of filling the existing gap. To provide an overview of the importance of the fear of being alone in people's lives, in one of these qualitative analyses, Cole (1999) noted that a stable relationship is a strong source 
of psychological security, with its absence being a cause of distress and anxiety in individuals who fear being without a partner.

Spielmann et al. (2013) developed and tested the quality of the instrument through seven studies. In the first study, participants were asked to describe what they thought about being single. The second study was divided into two stages: development and validation of the FBSS. The subsequent studies (from the third to the seventh) evaluated the instrument in different contexts (e.g., social media, universities, and events) and related it to different constructs (e.g., attachment, satisfaction with the relationship, and ideal partner). The results revealed that a person who scores high on the FBSS ends up being less demanding with regard to their relationships; they are less attractive and lack confidence.

As for its psychometric parameters, the instrument yielded satisfactory results in the exploratory analysis. Originally comprising 17 items, it was analyzed separately according to the participants' gender. After factor analysis, there remained eight items for men and 10 for women, with six items in common, presenting factor loadings above .67, which were chosen to be the final version of the instrument. Later, the structure with these six items was confirmed through a confirmatory factor analysis (CFA). The instrument presented Cronbach's alpha $(\alpha)$ of .86 , considered to be appropriate for measures that do not have a diagnosis as an objective (Kline, 2013).

Spielmann et al. (2013) checked its convergent validity to provide more results that demonstrate the quality of the scale. Significant and average magnitude correlations were observed (Cohen, 1988) between the instrument and the following constructs: sensitivity to rejection $(r=$ $.34, p<.001)$, depression $(r=.42, p<.001)$, loneliness $(r=.38, p<.001)$, and need to belong $(r=.43, p<.001)$, among others. Correlations of the FBSS were also performed with components of the Big Five (John \& Srivastava, 1999), obtaining significant and small magnitude results with all dimensions, namely: Neuroticism ( $r=$
$.28, p<.001)$, extraversion $(r=-.12 ; p<.05)$, conscientiousness $(r=-.16 ; p<.01)$, openness to experience $(r=-.12 ; p<.05)$, and agreeableness $(r=-.17 ; p<.01)$.

Knowing the importance of the results found by Spielmann et al. (2013) and the relevance of studies that may provide a better understanding about relationships and their effects on individuals, this study examined the validity of the FBSS in the Brazilian context through two studies. The first study examined how the instrument is presented in the Brazilian context. To this end, different factor retention methods (Kaiser, Cattell, Horn, optimal coordinates, and acceleration factor) were used and Principal Axis Factoring (PFA) was performed. The second study used the CFA to provide more robust evidence on this structure. The invariance of the instrument as a function of the relationship status of participants was also verified through a multigroup CFA (MGCFA). Then, in addition to ascertaining the levels of reliability of the scale, its convergence with other constructs, such as emotional and social loneliness and life satisfaction score, was also observed. Finally, the difference in means between men and women in the construct was examined. The results provide a further deepening of the theme as well as new alternatives for studies on relationships.

\section{Study 1 . The structure of the FBSS in Brazil}

The first study was exploratory, observing the structure of the instrument in Brazil. PFA and reliability analysis were performed.

\section{Participants}

This first study had 172 participants, with an average age of $23.69(S D=7.77)$, and $111 \mathrm{fe-}$ males $(64.5 \%)$. Most participants claimed to be Catholic ( $n=69 ; 40.1 \%)$, heterosexual ( $n=139$; $80.8 \%$ ), and in some type of serious relationship at the time of the survey $(n=101 ; 58.7 \%)$ from recent (for only one month) to long-term (lasting more than 10 years). Regarding marital status, most participants were single $(n=146 ; 84.9 \%)$. 


\section{Instruments}

The participants answered a questionnaire containing the FBSS and a demographic questionnaire to characterize the sample.

Fear of Being Single Scale (Spielmann et al., 2013). The FBSS was developed to explore the fears of people in being without a romantic companion. The instrument comprises six items (e.g., 3. I feel anxious when I think about being single forever; 6. As I get older, it will get harder and harder to find someone) which were answered on a scale of five points, ranging from 1 Not at all true to 5 Very true. The original scale showed a Cronbach's alpha $(\alpha)$ of 0.86 . Three bilingual collaborators helped in its translation, in which two translated the instrument into Portuguese and another made a back translation. Subsequently, we conducted a pilot study with the participation of 20 undergraduate students, equally distributed by gender, to verify the understanding of the items. After examining the instructions, scales of answers, and content, it was concluded that the scale was easy to understand.

Demographic Questionnaire. This contains questions that aim to characterize the research participants, namely, age, gender, sexual orientation, whether in a relationship and for how long, marital status, and religion.

\section{Procedure}

The application of this first study was performed through the Internet. More specifically, the questionnaire was drawn up on the Google Docs platform and shared through social media and emails. The first page of the site indicates the ethical principles, ensuring the anonymity of participants' responses and the right of voluntary participation, as well as the possibility to withdraw from the study at any time, with no risk or harm. In case of any doubt with regard to the questionnaire, participants could contact the researchers directly through e-mail.

The research was approved by the Ethics in Research with Human Beings of the Health Sciences Center, Universidade Federal da Paraiba (Protocol No. 0154/14) considering the ethical aspects required by the Resolution 466/2012.

\section{Data Analysis}

We used the statistical software R (R Development Core Team, 2015). Descriptive and frequency analyses were performed to characterize the sample. The Student's t-test, PFA, and reliability analysis (Cronbach's alpha; $\alpha$ ) were also performed.

Different statistical packages needed to be used to perform the analyses in the R software. To ascertain the Kaiser-Meyer-Olkim (KMO) criteria and Bartlett's sphericity test needed to extract factors, the statistical packages psych and corpcor (Revelle, 2013; Schäfer et al., 2013) were used, respectively. The packages psych and $n$ Factors were used to determine the number of factors that would be extracted (Raiche, Walls, Magis, Riopel, \& Blais, 2013). Finally, the psych and $\mathrm{ltm}$ packages were used (Rizopoulos, 2015) for the PFA and reliability analysis.

\section{Results}

First, the discriminative power of the items was verified to ascertain whether they were able to distinguish the participants who had answers with close magnitudes (Pasquali, 2003). The median point (13.00) was found through the sum of all six items of the scale, from which the two internal criteria groups, upper and higher, were established. Once these two groups were established, the Student's t-test was conducted to compare the means for each item, with all of them presenting statistically significant differences $(p<.001)$, as shown in Table 1 .

To verify the factorability of the correlations matrix between the items, it was necessary to observe the adequacy of data based on two criteria: the KMO and Bartlett's sphericity test. The values should be, respectively, equal to or greater than .60 and statistically significant (Tabachnick $\&$ Fidell, 2013). The results obtained support the factor analysis $[\mathrm{KMO}=.85$; Bartlett's sphericity test, $\left.\chi^{2}(15)=564.859, p<.001\right]$.

To decide on the number of factors that would be extracted from the FBSS, the criteria of Kaiser, Cattell, Horn, optimal coordinates, and acceleration factor were observed. The Kaiser criterion considers the specific values of the 
factors, which must be greater than 1 . The Cattell criterion is demonstrated through a graphical distribution of eigenvalues, which, when located after the "elbow," are disregarded. The parallel analysis (Horn criterion) is considered to be one of the most effective criteria, considering the higher eigenvalues in relation to those simulated. Through simulations, the optimal coordinates index verifies the number of simulations that are greater than the real eigenvalues, defining the number of factors to be extracted. The acceleration factor observes the point at which there is a change in the slope of the curve, identifying the factors found before the "elbow" (Raiche et al., 2013).

In all the criteria used, there was a uni-factor distribution for the instrument, a structure consistent with that proposed by Spielmann et al. (2013). Thus, the PFA was conducted, settling on a factor and considering items with saturation above $|.30|$ (Hair, Black, Babin, \& Anderson, 2015). The results can be seen in Table 2 .

Table 1

Discriminative Power of the Items in the Fear of Being Single Scale

\begin{tabular}{|c|c|c|c|c|c|c|}
\hline \multirow{3}{*}{ Items } & \multicolumn{4}{|c|}{ Group-Criterion } & & \\
\hline & \multicolumn{2}{|c|}{ Lower } & \multicolumn{2}{|c|}{ Higher } & \multicolumn{2}{|c|}{ Contrast } \\
\hline & $M$ & $S D$ & $M$ & $S D$ & $t$ & $p$ \\
\hline Item 1 & 1.71 & .94 & 3.83 & 1.08 & -13.75 & $<.001 *$ \\
\hline Item 2 & 1.20 & .48 & 2.60 & 1.44 & -8.43 & $<.001 *$ \\
\hline Item 3 & 1.30 & .55 & 3.75 & 1.10 & -18.18 & $<.001 *$ \\
\hline Item 4 & 1.25 & .69 & 3.30 & 1.56 & -11.02 & $<.001 *$ \\
\hline Item 5 & 1.84 & 1.19 & 3.69 & 1.31 & -9.70 & $<.001 *$ \\
\hline Item 6 & 1.51 & .91 & 3.25 & 1.30 & -10.18 & $<.001 *$ \\
\hline
\end{tabular}

Note. $M=$ mean; $S D=$ standard deviation.

$* p<.001$.

Table 2

Factorial Structure of the Fear of Being Single Scale

\begin{tabular}{lcc}
\hline \multicolumn{1}{c}{ Items } & Factor & $\mathrm{h}^{2}$ \\
\hline 3. I feel anxious when I think about being single forever. & $.90^{*}$ & .80 \\
1. It scares me to think there might not be anyone out there for me. & $.83^{*}$ & .68 \\
6. As I get older, it will get harder and harder to find someone. & $.73^{*}$ & .53 \\
4. I need to find a partner before I'm too old to have and raise children. & $.71^{*}$ & $.51 *$ \\
2. I feel it is close to being too late for me to find the love of my life. & .50 \\
5. If I end up alone in life, I will probably feel like there is something wrong with me. & $.63 *$ & .40 \\
Quantity of items & 6 & 57.1 \\
Explained variance (\%) & 3.43 \\
Eigenvalue & .88 \\
Cronbach's $\alpha$ & .56
\end{tabular}

Note. $*$ Factor loading considered satisfactory, that is, $>|.30| . \mathrm{h}^{2}=$ communality. 
All six items of the scale saturated above the cutoff point, with the structure and eigenvalue of 3.43 and explaining $57.1 \%$ of the total variance. Finally, the reliability of the instrument was verified, resulting in a Cronbach's alpha $(\alpha)$ of .88 , bringing together favorable evidence on the validity of this instrument. Furthermore, the scale also showed a homogeneity (mean interitem correlation) of .56, ranging from .34 to .76 .

\section{Study 2. Confirmatory analysis of the Fear of Being Single Scale}

The second study provided more robust evidence from the instrument. To this end, the structure was examined through a CFA as well as through the investigation of its factorial invariance, reliability, composite reliability (CR), and convergent validity.

\section{Participants}

The second study had the participation of 220 subjects, with an average age of $21.90(S D=$ 5.64), and 131 females (59.5\%). Many claimed to be Catholic ( $n=102 ; 46.4 \%)$, heterosexual ( $n$ $=206 ; 93.6 \%)$, and in a relationship at the time of answering the scale $(n=91 ; 41.4 \%$, ranging from one month to more than a decade, as in the first study). With regard to the marital status of the participants, the majority claimed to be single $(n=180 ; 81.8 \%)$.

\section{Instruments}

For the second study, in addition to using the same instruments as previously, the Loneliness Scale was used to verify the convergence of the instrument. At the end of the questionnaire, the score for the level of life satisfaction was also included (On a scale from 0 - Totally dissatisfied to 10 - Completely satisfied, how do you evaluate your satisfaction with life?).

Loneliness Scale by De Jong Gierveld (Short Version). This is an instrument created by Jong-Gierveld and Tilburg (2006) and validated for Brazil by Coelho, Fonsêca, Gouveia, Wolf, and Vilar (In press). It assesses the aspects of emotional loneliness (5. I often feel rejected) and social loneliness (6. There are enough people I feel close to) of individuals. It comprises six items and is answered on a five-point Likert scale $(1=$ Totally disagree $; 5=$ Totally agree $)$. In the validation for Brazil, it presented a Cronbach's alpha $(\alpha)$ of .77.

\section{Procedure}

Undergraduate students from the State of Paraíba participated in the second study. After approval by the professors, a timetable was agreed for the application of the questionnaires in the classroom. The researchers explained the research objectives to the students, as well as its ethical character, its guarantee of anonymity, of it being essentially voluntary, and the possibility of withdrawing if the student so desired. The researchers remained in the classroom throughout the application to answer any questions that might arise. The questionnaire was answered individually in a group setting.

\section{Data Analysis}

Descriptive analyses of frequency, reliability, and correlations, as well as Student's t-test were performed through the R software (R Development Core Team, 2015). As for the CFA, MGCFA, and CR, the AMOS software, version 22 , was used. Using the maximum likelihood estimation method, the following model indicators were considered to confirm the structure (Hair et al., 2015; Tabachnick \& Fidell, 2013):

- $\chi^{2}$ (chi-square)/df (Degrees of Freedom): Probability of the model fitting to the data obtained. The higher the value, the worse the fit. Values up to 5 are accepted but between 2 and 3 is recommended.

- Comparative fit index (CFI): Additional comparative index between the estimated model and the null model. Values closer to 1 indicate a satisfactory fit.

- Tucker-Lewis index (TLI): Global indicator of suitability of the model, assuming values between 0.80 and 0.90 and considering values close to 1.00 as satisfactory.

- Root mean square error of approximation (RMSEA): This is based on the residues of the 
model and is considered to be an indicator of a "bad" fit. High values indicate a misfit model, with values recommended between .05 and .08 , although values up to .10 are acceptable. The PClose tests the null hypothesis that RMSEA = .05 and should be greater than .05 to indicate a suitable model.

The MCFA was used to test the factorial invariance with respect to participants who are or are not in a relationship. To this end, the differences of chi-square $\left(\Delta \chi^{2}\right)$ were considered, which should be insignificant when comparing the models (Damásio, 2013), as well as the $\triangle$ RMSEA, which must be less than .015 (Chen, 2007).

\section{Results}

To confirm the results found in the first study, a uni-factor structure consistent with the original model was tested. All the indices showed satisfactory results: $\chi^{2} / d f=2.66, \mathrm{CFI}=$ $.96, \mathrm{TLI}=.94, \mathrm{RMSEA}=.087(90 \% \mathrm{CI}=.046-$ $.130)$, and PClose $=.067$.

Table 3

Factorial Invariance of the FBSS as to the Participants' Relationships

\begin{tabular}{ccccc}
\hline Models & $\chi^{2}(d f)$ & $\Delta \chi^{2}(d f)$ & RMSEA & ARMSEA \\
\hline Invariance of configuration & $33.004(18)$ & - & .062 & - \\
Metric invariance & $36.701(23)$ & $3.697(5)$ & .053 & .009 \\
Scale invariance & $54.767(29)$ & $18.066(6)^{*}$ & .064 & .011 \\
\hline
\end{tabular}

$* p<.05$.

It is observed that, using the $\Delta \chi^{2}$, the results support the invariance of configuration and metric invariance but do not support scale invariance; $\triangle \mathrm{RMSEA}$ shows support to the invariance across the three models used.

The convergence of the instrument was then tested with other constructs through correlations. The FBSS presented significant results with all the variables included, emotional loneliness $(r$ $=.36, p<.01)$, social loneliness $(r=.18, p<$ $.01)$, and the score for life satisfaction $(r=-.21$,
All factor loadings presented saturations between .49 (Item 6) and .82 (Item 3), showing to be statistically different from zero $(\lambda \neq 0 ; z>$ $1.96, p<.001)$, and with an average of .66. The scale presented a Cronbach's alpha $(\alpha=.88)$ and $\mathrm{CR}=.82$, reinforcing the internal consistency of the instrument.

Subsequently, the factorial invariance of the FBSS was tested as to whether or not the participants were in a relationship, using the MGCFA. To this end, three models were considered (Damásio, 2013): (a) Invariance of configuration or unrestricted model, which evaluates how plausible the structure of the scale is in relation to the groups in question; (b) Metric invariance or equality of factor loadings, which evaluates whether the factor loadings of the items are equivalent for the groups used; and (c) Scale invariance or invariance of intercepts, which assesses whether the intercepts of the items are equivalent for the groups. According to Milfont and Fischer (2010), these models are needed to test the scores of the two groups, with additional tests being optional. The results can be seen in Table 3. 


\section{Discussion}

Spielmann et al. (2013) attempted to overcome the limitations of previous studies on the fear of being single, considering that this fear does not necessarily end after finding a new partner, which indicates the need for more specific control and measuring. This fear can lead to concern, anguish, grief, or anxiety among people, in addition to settling for partners below expectation simply by having no hope for changing the situation (Cole, 1999). Thus, Spielmann et al. (2013) proposed the FBSS, for which this study aimed to present evidence of validity and internal consistency in the Brazilian context. The objective has apparently been achieved despite potential limitations regarding the studies, such as the use of non-probabilistic samples (for convenience) and the social desirability or response bias associated with self-report scales. However, this study evaluated the parameters of a specific scale.

In the first study, using different factor retention methods, we found a uni-factor structure identical to the original scale, with all items saturating above .63. These results were confirmed in the second study through a CFA. The indicators obtained support the uni-factor distribution obtained by the FBSS in the Brazilian context (Hair et al., 2015; Tabachnick \& Fidell, 2013). In addition, external validity of the scale was presented; in both studies, a Cronbach's alpha above that recommended by the literature was found regarding the reliability of the instruments (Kline, 2013) as well as evidence of their composite reliability (Škerlavaj \& Dimovski, 2009).

In the second study, an MCFA was also conducted to ascertain whether the scale presents equivalent configurations and parameters in relation to different groups (Damásio, 2013). In this case, participants' relationship status was used, whether they were single or not. The invariance was analyzed in relation to three different levels (configuration, metrics, and scale). The $\Delta \chi^{2}$ presented support only to the first two models. However, it should be emphasized that despite being an important tool to observe the differences in the population, $\chi^{2}$ has limitations, such as sensitivity to sample size and complexity of the model (Chen, 2007); thus, it is advisable to use it with another indicator (Damásio, 2013). In this case, it was used with the $\triangle$ RMSEA, which supported the invariance in the three models observed. Thus, the instrument was shown to be equivalent when answered by participants who are single as well as by those who are in a relationship.

Correlations among the FBSS, emotional and social loneliness, and the life satisfaction scores were performed in the second study. As expected, the correlation with emotional loneliness showed greater magnitude than with social loneliness. This type of loneliness is characterized by the lack of a closer relationship, such as a romantic partner, while social loneliness refers more to the individual's groups of interest, such as neighbors or co-workers (Jong-Gierveld \& Tilburg, 2010). Thus, a greater emotional loneliness could lead individuals to experience a greater fear for the future of their intimate relationships.

Despite the correlation with life satisfaction having only a low magnitude, it also had a significant result, indicating a negative relation among the variables. Single people are often stereotyped as "sadder" and having a "less exciting" life (Greitemeyer, 2009; Morris et al., 2007) as well as developing factors that destabilize their well-being and quality of life, such as low self-esteem, depression, and sensitivity to rejection (Hirschberger et al., 2002; Kavanagh et al., 2010; Spielmann et al., 2013).

Such negative assessments, cited by Spielmann et al. (2013), showed no distinction with regard to the gender of the participants, with the phenomenon occurring equally for both men and women. However, statistically significant differences were observed for this variable, noting that women had higher scores than men. Maio and Esses (2001) indicated the differences in the construction of masculinity and femininity in the process of social learning in relation to emotions. While men tend to avoid emotions, which would be a sign of weakness, women tend to welcome them. Guerra, Scarpati, Brasil, Livramento, and Silva (2015) corroborated the present authors, demonstrating that the emotional restriction for 
men is associated with personal stability and survival in groups that they are part of because the expression of emotions can be understood as a threat to masculinity. In addition, surveys have shown that women tend to experience more intense emotional loneliness than men (JongGierveld \& Tilburg, 2010; Pinquart and Sorensen, 2001), a type of loneliness that showed a significant positive correlation and average magnitude with regard to the fear of loneliness in the second study, which may help explain the greater fear presented.

For future studies, the use of other constructs is suggested to provide new evidence of convergent and divergent validity as well as to expand the possibility of studies on the fear of being single. These would be studies that address variables such as personality, positivity, self-esteem, and depression as well as constructs that allow a greater deepening in the field of relationships, such as jealousy and need for emotions, among other things. Finally, the importance of the results found should be emphasized since it is a phenomenon not yet studied in the Brazilian context, being able to provide discussions in various spheres, because of its psychological and social implications, especially on the wellbeing and quality of life of individuals.

\section{References}

Adamczyk, K., \& Segrin, C. (2015). Direct and indirect effects of young adults' relationship status on life satisfaction through loneliness and perceived social support. Psychologica Belgica, 55(4). doi:http://doi.org/10.5334/pb.bn

Almeida, S. M. T. (2015). Ficar solteiro ou investir numa relação? Motivações e efeitos no bemestar (Master's thesis, Universidade de Lisboa, Portugal). Retrieved from http://hdl.handle. net $/ 10451 / 23165$

Chen, F. F. (2007). Sensitivity of goodness of fit indexes to lack of measurement invariance. Structural Equation Modeling, 14, 464-504. doi:http:// dx.doi.org/10.1080/10705510701301834

Coelho, G. L. H., Fonsêca, P. N., Gouveia, V. V., Wolf, L. J., \& Vilar, R. (In press). De Jong Gierveld Loneliness Scale (Short Version): Validation to Brazilian Context. Paideia.
Cohen, J. (1988). Statistical power analysis for the behavioral sciences $\left(2^{\text {nd }}\right.$ ed.). Hillsdale, NJ: Erlbaum.

Cole, M. L. (1999). The Experience of never-married women in their thirties who desire marriage and children (Doctoral dissertation, Institute for Clinical Social Work, Chicago, IL). Retrieved from http://www.icsw.edu/_downloads/_dissertations/cole_1999.pdf

Conley, T. D., \& Collins, B. E. (2002). Gender, relationship status, and stereotyping about sexual risk. Personality and Social Psychology Bulletin, 28(11), 1483-1494. doi:http://doi. org/10.1177/014616702237576

Damásio, B. F. (2013). Contribuições da Análise Fatorial Confirmatória Multigrupo (AFCMG) na avaliação de invariância de instrumentos psicométricos. Psico-USF, 18(2), 211-220. doi:http:// doi.org/10.1590/S1413-82712013000200005

DePaulo, B. M. (2014). O melhor da vida de solteiro/a. Nova York: DoubleDoors Book.

DePaulo, B. M., \& Morris, W. L. (2005). Singles in Society and in Science. Psychological Inquiry, 16(2-3), 57-83. doi:http://doi.org/10.1080/1047 840X.2005.9682918

Etaugh, C., \& Malstrom, J. (1981). The Effect of Marital Status on Person Perception. Journal of Marriage and Family, 43(4), 801-805. doi:http:// doi.org/10.2307/351337

Gonçalves, E. (2011). Novas solteiras: Ecos do feminismo na mídia brasileira. Cadernos de Pesquisa, 41(12), 162-187.

Greitemeyer, T. (2009). Stereotypes of singles: Are singles what we think? European Journal of Social Psychology, 39(3), 368-383. doi:http:// doi.org/10.1002/ejsp.542

Guerra, V. M., Scarpati, A. S., Brasil, J. A., Livramento, A. M., \& Silva, C. V. (2015). Concepções de masculinidade: Suas associações com os valores e a honra. Psicologia e Saber Social, 4, 72-88. doi:http://doi.org/10.12957/psi.saber. soc. 2015.14840

Hair, J. F. J., Black, W. C., Babin, B. J., \& Anderson, R. E. (2015). Multivariate Data Analysis ( $7^{\text {th }}$ ed.). Upper Saddle River, NJ: Prentice Hall.

Hirschberger, G., Florian, V., \& Mikulincer, M. (2002). The anxiety buffering function of close relationships: Mortality salience effects on the readiness to compromise mate selection standards. European Journal of Social Psychology, 32(5), 609-625. doi:http://doi. org/10.1002/ejsp.110 
John, O. P., \& Srivastava, S. (1999). The Big-Five trait taxonomy: History, measurement, and theoretical perspectives. In L. A. Pervin \& O. P. John (Eds.), Handbook of personality: Theory and research (Vol. 2, pp. 102-138). New York: Guilford Press.

Jong-Gierveld, J., \& Tilburg, T. V. (2006). A 6-Item Scale for Overall, Emotional, and Social Loneliness Confirmatory Tests on Survey Data. Research on Aging, 28(5), 582-598. doi:http://doi. org/10.1177/0164027506289723

Jong-Gierveld, J., \& Tilburg, T. V. (2010). The De Jong Gierveld short scales for emotional and social loneliness: Tested on data from 7 countries in the UN generations and gender surveys. European Journal of Ageing, 7(2), 121-130. doi:http://doi.org/10.1007/s10433-010-0144-6

Kavanagh, P. S., Robins, S. C., \& Ellis, B. J. (2010). The mating sociometer: A regulatory mechanism for mating aspirations. Journal of Personality and Social Psychology, 99(1), 120-132. doi:http://doi.org/10.1037/a0018188

Kline, P. (2013). Handbook of Psychological Testing. New York: Routledge.

Maio, G. R., \& Esses, V. M. (2001). The need for affect: Individual differences in the motivation to approach or avoid emotions. Journal of Personality, 69(4), 583-614. doi:http://doi. org/10.1111/1467-6494.694156

Milfont, T. L., \& Fischer, R. (2010). Testing measurement invariance across groups: Applications in cross-cultural research. International Journal of Psychological Research, 3(1), 111-121.

Morris, W. L., Sinclair, S., \& DePaulo, B. M. (2007). No Shelter for Singles: The perceived legitimacy of marital status discrimination. Group Processes \& Intergroup Relations, 10(4), 457-470. doi:http://doi.org/10.1177/1368430207081535

Osin, E., \& Leontiev, D. (2013). Multidimensional Inventory of Loneliness Experience: Structure and properties. Psychology. Journal of Higher School of Economics, 10(1), 55-81. Retrieved from https://psy-journal.hse.ru/en/2013-101/78931776.html

Pasquali, L. (2003). Psicometria: Teoria dos testes na Psicologia e na Educação. Petrópolis, RJ: Vozes.

Pinquart, M., \& Sorensen, S. (2001). Influences on loneliness in older adults: A meta-analysis. Basic and Applied Social Psychology, 23(4), 245-266. doi:http://doi.org/10.1207/ S15324834BASP2304 2
R Development Core Team. (2015). R: A language and environment for statistical computing. Retrieved from https://cran.r-project.org/doc/manuals/fullrefman.pdf

Raiche, G., Walls, T. A., Magis, D., Riopel, M., \& Blais, J.-G. (2013). Non-graphical solutions for Cattell's scree test. Methodology: European Journal of Research Methods for the Behavioral and Social Sciences, 9(1), 23-29. doi:http://doi. org/10.1027/1614-2241/a000051

Revelle, W. (2013). Psych: Procedures for personality and psychological research. Retrieved from https://personality-project.org/r/psych.manual. pdf

Rizopoulos, D. (2015). Package "ltm": Latent Trait Models under IRT. Retrieved from https://cran.rproject.org/web/packages/ltm/ltm.pdf

Schäfer, J., Opgen-Rhein, R., Zuber, V., Ahdesmäki, M., Silva, A. P. D., \& Strimmer, K. (2013). Corpcor: Efficient estimation of covariance and (partial) correlation. Retrieved from http://cran. rproject.org/web/packages/corpcor/corpcor.pdf

Schwartzberg, N., Berliner, K., \& Jacob, D. (1995). Single in a married world: A life cycle framework for working with the unmarried adult. New York: W. W. Norton \& Company.

Sharp, E. A., \& Ganong, L. (2007). Living in the Gray: Women's Experiences of Missing the Marital Transition. Journal of Marriage and Family, 69(3), 831-844. doi:http://doi.org/10.1111/ j.1741-3737.2007.00408.x

Škerlavaj, M., \& Dimovski, V. (2009). Organizational learning and performance in two national cultures: A multi-group structural equation modeling approach. In W. R. King (Ed.), Knowledge Management and Organizational Learning (pp. 321-367). Pittsburgh, PA: Springer US.

Spielmann, S. S., MacDonald, G., Maxwell, J. A., Joel, S., Peragine, D., Muise, A., \& Impett, E. A. (2013). Settling for less out of fear of being single. Journal of Personality and Social Psychology, 105(6), 1049-1073. doi:http://doi. org/10.1037/a0034628

Tabachnick, B. G., \& Fidell, L. S. (2013). Using Multivariate Statistics $\left(6^{\text {th }}\right.$ ed.). Boston, MA: Allyn and Bacon. 